Available online on 15.11.2020 at http://ujpr.org
Universal Journal of Pharmaceutical Research
An International Peer Reviewed Journal
Open access to Pharmaceutical research is an open access article distributed under the terms of the Creative Commons Attribution-Non
Commercial Share Alike 4.0 License which permits unrestricted non commercial use,
provided the original work is properly cited
Volume 5, Issue 5, 2020

\title{
SIDE EFFECTS OF CYCLOSPORINE COMPARED TO TACROLIMUS AMONG YEMENI KIDNEY TRANSPLANT PATIENTS WHO SHARE THE SAME ADJUVANT AGENTS: MYCOPHENOLATE MOFETIL AND PREDNISONE
} Ibtesam Abdullah Al-Akwa'a1 ${ }^{1}$, Nagieb Waza'a Abu Asba ${ }^{2}$, Khaled Abdl Karim Al-Moyed ${ }^{3}$, Hassan Abdul Wahab Al-Shamahy ${ }^{3}{ }^{1}$, Ahmed M. Al-Haddad ${ }^{4}$

${ }^{I}$ The National Center for Public Health Laboratories in Sana'a, The Ministry of Health and Population, Sana'a, Yemen. ${ }^{2}$ Urology and Nephrology Center, Al-Thawra Hospital, Sana'a University, Sana'a, Yemen.

${ }^{3}$ Department of Medical Microbiology and Clinical Immunology, Faculty of Medicine and Health Sciences, Sana'a University. ${ }^{4}$ Department of Medical Laboratories, College of Medicine and Health Sciences, Hadhramout University, Al-Mukalla, Yemen.

\section{ABSTRACT}

Background: A renal allograft is the optimum therapeutic option for patients with end stage renal diseases. Nevertheless, rejection still represents a large challenge. So as to overcome this matter, treatment strategies comprise the combined use of antiinflammatory and immunosuppressive agents, although they are not free from complications . Interestingly, the major cause of morbidity and mortality after the first transplanted year are due to disorders unrelated directly to immunologic etiology or disease related to immunosuppressive drugs.

Objectives: The purpose of this study is to determine the side effects in renal transplant Yemeni patients adherence to cyclosporine compared to tacrolimus sharing the same adjuvant agents which are mycophenolate mofetil "MMF" and prednisone. Subject and methods: This prospective study was carried on 100 kidney transplanted Yemeni patients divided into two groups: cyclosporine group $(n=50)$ and tacrolimus group $(n=50)$, each member of these groups was visited three times, blood samples were collected for biochemical functions including fasting blood sugar, liver enzymes, kidney functions, lipid profiles and white blood cells counts and results were obtained from the tests performed. Body weight and blood pressure had been examined; clinical complications were also recorded.

Results: This study showed that serum total and direct bilirubine, gamma glutamyl transferase "GGT" and lipid profiles were elevated in cyclosporine group, whereas in tacrolimus group they were within normal range. The incidence of complicated events reported as follows: Hairtusim, gum hyperplasia, herpeszoster, CUSHING face and obesity were obviously present in cyclosporine group, while in tacrolimus group diabetes mellitus, hair loss and gastrointestinal tract infections were in existence.

Conclusion: This study found that a tacrolimus-based treatment was significantly better than an immunosuppressive regimen based on cyclosporine due to the generally less side effects associated with tacrolimus, despite its effect on increasing diabetes among kidney transplant patients.

Keywords: Cyclosporine, mycophenolate mofetil "MMF", prednisone, renal transplant, side effects, tacrolimus, Yemen.

Article Info: Received 18 August 2020; Revised 25 September; Accepted 20 October, Available online 15 November 2020

Cite this article-

Al-Akwa'a IA, Abu-Asba NWA, Al-Moyed KAK, Al-Shamahy HA, Al-Haddad AM. Side effects of cyclosporine compared to tacrolimus among Yemeni kidney transplant patients who share the same adjuvant agents: mycophenolate mofetil and prednisone. Universal Journal of Pharmaceutical Research 2020; 5(5):32-38.

DOI: https://doi.org/10.22270/ujpr.v5i5.484

Address for Correspondence

Dr. Hassan Abdul Wahab Al-Shamahy, Faculty of Medicine and Heath Sciences Sana'a University, P.O. Box 775 Sana'a, Yemen, Tel: +967-770299847, E-mail: shmahe@yemen.net.ye

\section{INTRODUCTION}

Kidney transplantation is the ideal action for most patients with end-stage kidney disease (ESRD) ${ }^{1}$. Kidney transplantation for patients with ESRD can enhance survival and quality of life, and lower the cost of health care. Currently, the 1-year patient survival rates and graft survival rates are $94 \%$ and $82 \%$, respectively ${ }^{2,3}$. The incidence of ESRD in Yemen is 120 cases per million annually, which is comparable to the incidents reported in other posts in the same region $^{4,5,6}$. In Yemen, the kidney transplant program began intermittently since 1998. However, there has been a well-established program that has been running regularly since the beginning of 2005 in the Urology and Nephrology Center at Al-Thawra Modern General 
Hospital, Sana'a ${ }^{7}$. Despite significant advances in the field of kidney transplantation, long-term graft survival has not increased significantly due to the continuing effect of immunosuppressive and infectious disease on transplant recipients ${ }^{8,9}$.

Several immunosuppressive agents are currently in use in protective immunity in kidney transplant recipients. Usually utilized oral immunosuppressive agents fall into three categories: calcineurin inhibitors (cyclosporine and tacrolimus), antiproliferative agents (azathioprine and mycophenolate mofetil) and steroids (prednisone). The combined use of one agent in each class is known as triple therapy, and it is the standard regimen for early to mid-term immunosuppression after transplantation. This provides broad immunosuppression based on the different mechanisms of action for each group ${ }^{10}$. Medicines are not with no challenges and hazards. Patients need to maintain to take immunosuppressive drugs for the rest of their lives to obstruct allograft rejection, and this trend to morbidity and mortality from organ failure to risks of cancer and infection. Additionally, these drugs are on the verge of contribute to increased mortality from cardiovascular disease, which is the leading cause of premature death in kidney transplant recipients ${ }^{10}$. At the time of transplantation to achieve adequate immunosuppression and to prevent acute rejection attacks, Cyclosporine A (CyA) and tacrolimus (TAC), are used as calcineurin inhibitors ${ }^{3}$. CyA was revealed in 1971, and in 1983, this drug was permitted for the prevention of organ transplant rejection. TAC (Prograf) was discovered in the early 1980's and from 1989, and is used to prevent liver transplant rejection. After that, the use of this drug quickly developed for transplantation of other organs ${ }^{11}$.

Because of the possibility of different effects in Yemeni patients compared to other nationalities, and also that there was no study on this topic in advance in Yemen, so this follow-up study was done with the aim of evaluating the differences in kidney transplant patients, who share the same immunosuppressive adjuvants, which are mycophenolate mofetil. MMF '+ prednisone but differs in the calcineurin inhibitor, one group used cyclosporine and another group used tacrolimus regarding its effect on kidney and liver function, lipid properties, and complete blood cell count. Also investigating the possible relationship between the group's cyclosporine and tacrolimus with respect to other clinical side effects such as hypertension, diabetes, obesity, and dysmorphic changes.

\section{SUBJECTS AND METHODS}

This study was conducted at Al-Thawra Hospital and the National Center for Public Health Laboratories in Sana'a on one hundred Yemeni patients with kidney transplants ranging in age (14 - 60 years): 59 men and 41 females between September 2016 to September 2017. They were divided into two groups: (Group A) 50 patients (39 males, 11 females) on a cyclosporinebased immunosuppressant regimen, (group B) 50 patients (20 males and 30 females) with a tacrolimus- based immunosuppressive regimen. All patients were informed of the aim of the study and gave their consent. Both drugs were administered in two divided doses and the dose was adjusted according to clinical responses and blood trough levels for 12 hours. The whole blood trough level of tacrolimus was maintained between $5-15 \mathrm{ng} / \mathrm{ml}$ and cyclosporine between 100-200 $\mathrm{ng} / \mathrm{ml}$. Doses were tapered based on the concentration of the drug in whole blood and clinical examination.

Sample processing: Blood samples were drawn for all measurements in the morning from 8 am to $11 \mathrm{am}$. Two tubes with EDTA one for cyclosporine or tacrolimus and the second for $\mathrm{CBC}$, another plain tube for chemical parameters. Analysis was performed on the same day of collection and results were recorded at three-month intervals. The samples were taken for analysis of cyclosporine and tacrolimus blood levels, fasting blood sugar, kidney function tests (KFT) including urea and creatinine tests, liver functions tests (LFT) included bilirubin total and direct, glotamate oxaloacetate transaminase GOT, glutamate pyruvate transaminase GPT, alkaline phosphataes ALK, and gamma glutamate transaminase GGT tests, lipid profiles (total cholesterol, high density lipoprotein ,low density lipoprotein and triglyceride) also the complete blood count CBC were determined. Blood pressure and body weight were also recorded with an automatic scale. Data from the renal recipient records were investigated retrospectively to determine the immunosuppressant complications among the renal allograft recipients.

Ethical consideration: Ethical approval was obtained from the Ethical Committee of the medical research at Sana'a University. Approval was obtained from all participants before recruiting them to the study and after explaining for them the aim of the study.

Statistical analysis: Data of completed questionnaire obtained, and were manipulated using Statistical Package for the Social Science version 21.0 software (SPSS version 21.0).

Table 1: The patient characteristics.

\begin{tabular}{|c|c|c|c|c|c|c|}
\hline \multirow[t]{2}{*}{ Character } & \multicolumn{2}{|c|}{$\begin{array}{c}\text { Cyclosporine } \\
\text { group }\end{array}$} & \multicolumn{2}{|c|}{$\begin{array}{c}\text { Tacrolimus } \\
\text { group }\end{array}$} & \multicolumn{2}{|c|}{ Total } \\
\hline & No & $\%$ & No & $\%$ & No & $\%$ \\
\hline \multicolumn{7}{|l|}{ Sex } \\
\hline Male & 39 & 78 & 20 & 40 & 59 & 59 \\
\hline Female & 11 & 22 & 30 & 60 & 41 & 41 \\
\hline Total & 50 & 100 & 50 & 100 & 100 & 100 \\
\hline \multicolumn{7}{|l|}{ Age group } \\
\hline$<15$ years & 0 & 0 & 1 & 2 & 1 & 1 \\
\hline $15-25$ years & 15 & 30 & 18 & 36 & 33 & 33 \\
\hline $26-35$ years & 16 & 32 & 17 & 34 & 33 & 33 \\
\hline $36-45$ years & 11 & 22 & 10 & 20 & 21 & 21 \\
\hline$>45$ years & 8 & 16 & 4 & 8 & 12 & 12 \\
\hline Total & 50 & 100 & 50 & 100 & 100 & 100 \\
\hline
\end{tabular}

\section{RESULTS}

The recipient's age, ranged from 14-60 years and their mean age was 32.4 years in both groups. A significant difference was only found in recipients aged at $>45$ years as in cyclosporine group was $16 \%$ while in tacrolimusit it was $8 \%$. With regard to gender $78 \%$ 
male and $22 \%$ female have been found in cyclosporine group while in tacrolimus group were $40 \%$ male and $60 \%$ female (Table 1). Their causes of renal failure was clinically diagnosed as follows: Hypertension (37\%), Kidney atrophy (14\%), Chronic urinary tract infection $(14 \%)$, Stones (10\%), Antibiotic abuse (4\%), Hereditary (4\%), Diabetes mellitus (3\%), and (14\%) unknown cause (Table 2).

Table 2: The original causes of renal failure among our study group.

\begin{tabular}{lcccccc}
\hline \multirow{2}{*}{ Character } & \multicolumn{3}{c}{$\begin{array}{c}\text { Cyclosporine } \\
\text { group }\end{array}$} & $\begin{array}{c}\text { Tacrolimus } \\
\text { group }\end{array}$ & Total \\
\cline { 2 - 7 } & No & \% & No & \% & No & $\%$ \\
\hline Hypertension & 21 & 42 & 16 & 32 & 37 & 37 \\
Kidney atrophy & 7 & 14 & 7 & 14 & 14 & 14 \\
Recurrent UTI & 6 & 12 & 8 & 16 & 14 & 14 \\
Obstructive Nephropathy & 4 & 8 & 6 & 12 & 10 & 10 \\
Hereditary & 2 & 4 & 2 & 4 & 4 & 4 \\
Antibiotic abuse & 1 & 2 & 3 & 6 & 4 & 4 \\
Diabetes mellitus & 2 & 4 & 1 & 2 & 3 & 3 \\
Unknown & 7 & 14 & 7 & 14 & 14 & 14 \\
Total & 50 & 100 & 50 & 100 & 100 & 100 \\
\hline
\end{tabular}

All renal recipients received a single kidney from a living donors aged between 18-55 years, in cyclosporine group (46\%) of the donors were relatives and $(54 \%)$ were non-relatives, while in tacrolimus group $(72 \%)$ of the donors were relatives and $(28 \%)$ were non-relatives. Also the drugs levels were similar in both groups; $62 \%$ and $64 \%$ of the cyclosporine and tacrolimus respectively and were within normal ranges of the trough blood level which is $100-200 \mathrm{ng} / \mathrm{ml}$ for cyclosporine and 5-15 ng/ml for tacrolimus, and 38\% in cyclosporine group and 36\% in tacrolimus group were shifted from their trough blood level (Table 3).

Table 3: The drug monitoring levels during study.

\begin{tabular}{lllcccccc}
\hline Character & $\begin{array}{c}\text { Cyclosporine } \\
\text { group }\end{array}$ & \multicolumn{2}{c}{$\begin{array}{c}\text { Tacrolimus } \\
\text { group }\end{array}$} & & Total & P \\
\cline { 2 - 9 } & No & \% & No & \% & No & \% & \\
\hline Decrease & 0 & 0 & 1 & 2 & 1 & 1 & \\
Normal & 31 & 62 & 32 & 64 & 63 & 63 & \\
Increase & 19 & 38 & 17 & 34 & 36 & 36 & 0.16 \\
Total & 50 & 100 & 50 & 100 & 100 & 100 & \\
\hline
\end{tabular}

The post transplant means values of sugar, LFT, KFT, and lipid profiles are summarized in (Table 4), the significant difference were found in the elevation of total and direct bilirubin, GGT, total cholesterol, LDL, HDL, and triglycerides in cyclosporine group while not in tacrolimus group $(P<0.0001)$. No differences in the other biochemical test parameters detected between the two groups as shown in table 4 . There was a significant difference in $\mathrm{Hb}(p<0.0001)$ and platelits $(p<0.023)$ while no difference had been found in WBCs between the two groups (Table 5). The incidence of adverse events reported in Table 6 included: $64 \%$ hairtusim, $54 \%$ obesity, $16 \%$ gum hyperplasia, $22 \%$ Cushing face, $10 \%$ herpes zoster, $28 \%$ herpes simplex, and 2\% Kaposi sarcoma were associated with cyclosporine group, and this was significant. On the other hand gastrointestinal infection 24\%, DM 20\%, hair loss $20 \%$ , $10 \%$ gastritis and had been found in tacrolimus group while not in cyclosporine group. Total $12 \%$ of cyclosporine group and $8 \%$ of tacrolimus group had no complications during the follow up time (one year).

Table 4: The main effects of Cyclosporine and Tacrolimus in biochemical functions in a hundred renal recipients (Mean \pm S.D).

\begin{tabular}{|c|c|c|c|}
\hline $\begin{array}{l}\text { Character } \\
\text { (normal } \\
\text { range) }\end{array}$ & $\begin{array}{c}\text { Cyclosporine } \\
\text { group }=\mathbf{5 0}\end{array}$ & $\begin{array}{c}\text { Tacrolimus } \\
\text { group=50 }\end{array}$ & $P$ \\
\hline $\begin{array}{c}\text { Sugar } \\
(3.05-6.38 \mathrm{mmol} / \mathrm{L})\end{array}$ & $5.39 \pm 1.67$ & $5.6 \pm 2.1$ & 0.581 \\
\hline $\begin{array}{c}\text { Urea } \\
(1.5-8.3 \mathrm{mmol} / \mathrm{L}) \\
\end{array}$ & $6.18 \pm 2.1$ & $7.99 \pm 8.3$ & 0.143 \\
\hline $\begin{array}{r}\text { Creatinine } \\
(55-124 \mathrm{mmol} / \mathrm{L}) \\
\end{array}$ & $113 \pm 32.5$ & $116 \pm 74.4$ & 0.761 \\
\hline $\begin{array}{c}\text { T-bil } \\
\text { (up to } 18 \mathrm{mmol} / \mathrm{L} \text { ) }\end{array}$ & $14.8 \pm 7.8$ & $9.4 \pm 5.7$ & $<.0001^{*}$ \\
\hline $\begin{array}{c}\text { D-bil } \\
\text { (up to } 5.1 \mathrm{mmol} / \mathrm{L} \text { ) }\end{array}$ & $4.8 \pm 2.7$ & $2.2 \pm 1.6$ & $<.0001 *$ \\
\hline $\begin{array}{c}\text { Got } \\
\text { ( up to 35U/L) }\end{array}$ & $25.3 \pm 25.1$ & $23.2 \pm 24.5$ & 0.686 \\
\hline $\begin{array}{c}\mathrm{Gpt} \\
\text { (up to } 40 \mathrm{U} / \mathrm{L} \text { ) }\end{array}$ & $35.3 \pm 46.4$ & $24.9 \pm 17.1$ & 0.139 \\
\hline $\begin{array}{c}\text { Alk } \\
(35-129 \mathrm{U} / \mathrm{L})\end{array}$ & $112.5 \pm 45.9$ & $98.4 \pm 42$ & 0.112 \\
\hline $\begin{array}{c}\text { GGT } \\
(5-61 \mathrm{U} / \mathrm{L})\end{array}$ & $59.8 \pm 72.2$ & $29.1 \pm 11.4$ & $0.004 *$ \\
\hline $\begin{array}{c}\text { CHOL } \\
\text { (up to } 200 \mathrm{mg} / \mathrm{dl} \text { ) }\end{array}$ & $209.2 \pm 47.4$ & $144.1 \pm 39.8$ & $<.0001 *$ \\
\hline $\begin{array}{c}\text { HDL } \\
(>35 \mathrm{mg} / \mathrm{dl})\end{array}$ & $42.3 \pm 12.0$ & $34.7 \pm 5.2$ & $<.0001 *$ \\
\hline $\begin{array}{c}\text { LDL } \\
(<150 \mathrm{mg} / \mathrm{dl}) \\
\end{array}$ & $128.3 \pm 36.7$ & $81.8 \pm 31.5$ & $<.0001 *$ \\
\hline $\begin{array}{c}\mathrm{TG} \\
\text { (up to } 200 \mathrm{mg} / \mathrm{dl} \text { ) }\end{array}$ & $235.3 \pm 109.8$ & $157.8 \pm 60.4$ & $<.0001 *$ \\
\hline
\end{tabular}


Table 5: The main effects of Cyclosporine and Tacrolimus in complete blood count "CBC" in a hundred renal recipients (Mean \pm S.D).

\begin{tabular}{cccc}
\hline $\begin{array}{l}\text { Character } \\
\text { (normal range })\end{array}$ & $\begin{array}{c}\text { Cyclosporine } \\
\text { group =50 }\end{array}$ & $\begin{array}{c}\text { Tacrolimus } \\
\text { group =50 }\end{array}$ & $\boldsymbol{P}$ \\
\hline $\mathrm{Hb}$ & $145.8 \pm 17.6$ & $144.1 \pm 39.8$ & $<.0001^{*}$ \\
$(115-180 \mathrm{~g} / \mathrm{l})$ & & & \\
\hline $\begin{array}{c}\mathrm{WBC} \\
\left(4-10 \times 10^{9} \mathrm{cell} / \mathrm{L}\right)\end{array}$ & $8.3 \pm 2.6$ & $8.3 \pm 2.6$ & 0.998 \\
\hline $\begin{array}{c}\mathrm{Plts} \\
\left(150-400 \times 10^{9} \mathrm{cell} / \mathrm{L}\right)\end{array}$ & $267.5 \pm 71.1$ & $238.9 \pm 50.4$ & $.023^{*}$ \\
\hline & $*$ Significant & & \\
\hline
\end{tabular}

Table 6: The complications of Cyclosporine group and Tacrolimus group in a hundred renal allograft recipients.

\begin{tabular}{|c|c|c|c|c|c|}
\hline \multirow[t]{2}{*}{ Character } & \multicolumn{2}{|c|}{$\begin{array}{c}\text { Cyclosporine } \\
\text { group }\end{array}$} & \multicolumn{2}{|c|}{$\begin{array}{l}\text { Tacrolimus } \\
\text { group }\end{array}$} & \multirow[t]{2}{*}{$P$} \\
\hline & No & $\%$ & No & $\%$ & \\
\hline Gum hyperplasia & 8 & 16 & 0 & 0 & $0.003 *$ \\
\hline Hairtusim & 32 & 64 & 2 & 4 & $<.001 *$ \\
\hline Being diabetic & 1 & 2 & 10 & 20 & $0.004 *$ \\
\hline Herpes zoster & 5 & 10 & 0 & 0 & $0.001 *$ \\
\hline GITI & 7 & 14 & 12 & 24 & 0.2 \\
\hline UTI & 4 & 8 & 5 & 10 & 0.7 \\
\hline Couching face & 11 & 22 & 0 & 0 & $<.001 *$ \\
\hline Fatigue & 9 & 18 & 11 & 22 & 0.6 \\
\hline Kaposi sarcoma & 1 & 2 & 0 & 0 & 0.15 \\
\hline Hair loss & 0 & 0 & 10 & 20 & $0.001 *$ \\
\hline Polycythemia & 0 & 0 & 1 & 2 & 0.3 \\
\hline Gastritis & 2 & 4 & 5 & 10 & 0.23 \\
\hline Obesity & 27 & 54 & 14 & 28 & $<.001 *$ \\
\hline Hypertension & 12 & 24 & 5 & 10 & 0.09 \\
\hline Herpes simplex & 14 & 28 & 3 & 6 & 0.003 \\
\hline No complication & 6 & 12 & 4 & 8 & 0.5 \\
\hline
\end{tabular}

\section{DISCUSSION}

The results of this study showed that the fasting blood sugar levels in both groups were similar and at the top of their normal range. Although, diabetes mellitus as a clinical complication appeared in $20 \%$ of tacrolimus group whereas in cyclosporine group was only $2 \%$. This is in agreement with the fact that after renal transplantation some $45 \%$ of patients may show abnormal glucose tolerance and 20-25\% may develop diabetes ${ }^{12}$. Another study showed that tacrolimus is associated with diabetes mellitus, due to the increased concentration of FKBP (FK binding protein) in pancreatic islets relative to cyclophiline during drugs metabolism. Morphologic changes in the islets comprise vacuolization, cytoplasmic swelling and apoptosis, plus normal immune-staining for insulin, this outcome is dose related and may be amplified by concomitant corticosteroid use especially prednisone ${ }^{13}$. Some previous studies suggested that tacrolimus affects glucose metabolism by reducing insulin secretion in the pancreas in a dose-dependent manner ${ }^{14}$. Initially, an increased insulin resistance was also reported $^{15}$, but this seems to be the result of the coadministration of steroids $^{14}$. Both prednisone and calcineurin - inhibitors provide additional risk factors, with tacrolimus conveying an increased risk, as compared to cyclosporine. Corticosteroids have been shown to produce peripheral insulin resistance and to cause alteration in pancreatic beta-cell insulin secretion. Cyclosporine and tacrolimus also appear to alter peripheral insulin sensitivity and to diminish islet function $^{16}$. In the current study, the mean serum values of urea and creatinine were at the upper limit of their normal range. This is supported by another study, which reported that both cyclosporine and tacrolimus produce a chronic arteriolopathy and chronic toxicity with irreversible kidney damage ${ }^{17}$ and this elevation indicate a significant, potentially graft-endangering event $^{18}$. Calcineurin inhibitors CsA and FK506 generate dose-related reversible renal vasoconstriction that specifically affects the afferent arteries, the glomerular capillary ultrafiteration coefficient also decreases. Most of the studies on the mechanism of this effect have used cyclosporine rather than tacrolimus ${ }^{19}$. This have explained why cyclosporine affect on kidney function is obvious, as the main adverse effect of cyclosporine is nephrotoxicity, long-term use of CsA can lead to chronic toxicity associated with an irreversible and progressive decrease in renal function and this is characterized by interstitial fibrosis and degenerative hyaline changes in the walls of the connecting arteries ${ }^{20}$, this lead to vasoconstriction that causes acute reversible decrease in GFR" glumerular filtration rate"21. Although this study have shown that the blood concentration of urea and creatinine were higher in tacrolimus group (urea: $7.99 \pm 8.3$, creatinine: $116 \pm 74.7$ ) than in cyclosporine group (urea: 6.18 \pm 2.1 , creatinine: $113 \pm 32.5$ ), this is not agreement with some studies that indicated tacrolimus and MMF" 
mycophenolate mofetil " significantly improved kidney function $^{22}$, and the serum creatinine concentrations were better in tacrolimus group, due to $\mathrm{MMF}^{23}$. But agreement with a study reported that, the majority of renal transplant patients tolerate long-term cyclosporine therapy without evidence of progressive toxic nephropathy ${ }^{24}$. There was a significant increase in total, direct bilirubin blood levels and gamma glutamyl transpeptidase "GGT" in cyclosporine group rather than tacrolimus group. This is in agreement with the study that reported episode of hepatic dysfunction typically manifesting as sub clinical, mild, self limiting, and dose-dependent increase of serum aminotransferase levels with slight hyperbilirubinemia occur in nearly half of all kidney transplant recipients taking cyclosporine and occur less frequently in those taking tacrolimus. No specific hepatic tissue lesion has been described in humans, hyperbilirubinemia is a reflection of disturbed bile secretion rather than hepatocyte damage, and cyclosporine itself does not result in progressive hepatic disease; another reason, most often one of the causes of viral hepatitis, even some studies have found that both cyclosporine and tacrolimus cause liver toxicity and impair liver function $^{26,27}$.

Lipid profiles including total cholesterol, HDL, LDL, TG were significantly altered with cyclosporine and elevated in comparison to tacrolimus group in the current study. This results were similar to those obtained by another studies which assessed hyperlipidemia is one of the metabolic adverse effects of cyclosporine and tacrolimus but its greater in cyclosporine A than in tacrolimus the mechanism related to cyclosporine alteration of lipids is through its direct effect on cell membrane cholesterol concentration and regulatory pools, resulting in both increased synthesis of cholesterol and decreased clearance of LDL, HDL levels are typically normal or elevated in obesity; however cardio protective HDL fraction may remain low ${ }^{28,30}$

The total blood cell counts were similar in the two study groups, and this is in agreement with another studies that assessed cyclosporine A and corticosteroids which have no suppressor effects on bone marrow cells, also mycophenolate mofetil usually do not cause bone marrow suppression ${ }^{31}$, even if another study found that prednisone inhibited the expression of polymorphoneutriphils to the tissue. This lead in turn to their accumulation in the peripheral blood $^{32}$. Even severe anemia appeared due to selective depression of erythropoiesis by immunosuppressive $\operatorname{drugs}^{33}$, anemia resolved when tacrolimus was replaced with cyclosporine, more generalized bone marrow suppression has also been reported ${ }^{34}$. This result was shown as significant difference between the two groups , although hemoglobin was within normal range ,as the excellent graft function is achieved, a burst of erythropoietin secretion is normally followed by effective production of erythrocytes ${ }^{35}$. There was a significant difference in platelets between the two groups, it seems to be thrombocytosis in cyclosporine group, but not in agreement with a study that reported thrombocytopenia is associated with cyclosporine therapy ${ }^{36}$. There was a significant presence of gingival hyperplasia or gum hyperplasia in cyclosporine group while not in tacrolimus group. These findings are consistent with the results obtained from other studies which reported that cyclosporine is well known to be associated with the development of gingival overgrowth $^{37}$, the reason for this localization of this effect in the gums is not known, although it is possible that the periodontal tissues are exposed to higher concentrations of drugs compared to other tissues, and this is strong evidence that the drug works on the growth and function of both gingival fibroblasts and gingival epithelial cells via cytokines and growth factors $^{38}$. CsA may also cause gingival hyperplasia by increasing the number of fibroblasts and the production of collagen by them ${ }^{39}$. It was shown that Hirstism is significantly incidence in cyclosporine group while hair loss is significantly found in tacrolimus group, and these were supported by another study that reported Hirstism found in cyclosporine ${ }^{40}$ and hair loss in tacrolimus ${ }^{41}$. CsA may cause hypertrichosis on the face, arms, shoulders, and back, and is particularly troublesome in young women and children, particularly if dark-haired. This disorder is dose-dependent, and, at least in experimental animals, seems to be related to the inhibition of NFAT in follicular keratinocytes ${ }^{42}$.

A significant difference in herpes zoster and Kaposi sarcoma and dysmorphic changes that were found more in cyclosporine in the current study. This is in concordance with the results obtained in another study which found that the herpes zoster develops in approximately $10 \%$ of adult renal transplant recipients and may involve two to three adjoining dermatomes; infection is usually caused by reactivation of latent diseases. Post transplant infection can be primary or transmitted from the donor kidney and is associated with Kaposi sarcoma occurring at median of 30 months post transplant. Diagnosis is supported by pathology and by the presence of human herpes viruses ${ }^{43}$.

There was no significant difference in hypertension as a complicated disease' between cyclosporine and tacrolimus groups and this is supported by other studies that reported hypertension as common after transplantation and may be caused by the effect of cyclosporine or tacrolimus ${ }^{44}$, Cyclosporine may cause renal vasoconstriction through several mechanisms ${ }^{45}$. As a consequence, there is a reduction of glomerular filtration rate and of renal blood flow ${ }^{46}$. In turn, these functional abnormalities lead to retention of salt and water, to an increase in extracellular fluids, and to an increased cardiac output ${ }^{47}$.

The apparently normal production of renin by the allograft and by the native kidney is inappropriately elevated in a setting characterized by extracellular fluid expansion, collaborating with hypertension ${ }^{48}$. Tacrolimus also produces clinical post-transplant hypertension via mechanisms similar to those of cyclosporine $^{49}$ although hypertension is less common in patients given tacrolimus than in those receiving cyclosporine $^{50}$. There is a significant difference in obesity in the two study groups, it was clearly obvious in cyclosporine group due to high appetite in these 
patients and this is associated with steroid therapy that potentate in combination with cyclosporine ${ }^{51}$.

\section{CONCLUSION}

This study found that a tacrolimus-based treatment was significantly better than an immunosuppressive regimen based on cyclosporine due to the generally less side effects associated with tacrolimus, despite its effect on increasing diabetes among kidney transplant patients. We also hope to conduct more studies to prevent widespread renal failure by knowing the factors predisposing to kidney failure and researching factors that can affect medical compliance after kidney transplantation in Yemen.

\section{AUTHOR'S CONTRIBUTION}

This research work is part of the MA thesis. The candidate, Ibtisam Al-Akwa, conducted the laboratory work and wrote the thesis. The second author (NAS) conducted and supervised the clinical works. The Corresponding Author (HAA), Third Author (KAM), and the rest of the authors oversaw the work, reviewing and editing the draft and manuscript.

\section{ACKNOWLEDGEMENTS}

Authors acknowledge the financial support of Sana'a University, Sana'a City, Yemen.

\section{CONFLICT OF INTEREST}

No conflict of interest associated with this work.

\section{REFERENCES}

1. Webster AC, Woodroffe RC, Taylor RS, Chapman JR, Craig JC. Tacrolimus versus ciclosporin as primary immunosuppression for kidney transplant recipients: Metaanalysis and meta-regression of randomised trial data. BMJ 2005;331:810 PMCID: PMC1246079 PMID: 16157605

2. Tsipotis E, Gupta NR, Raman G, Zintzaras E, Jaber BL. Bioavailability, efficacy and safety of generic immunosuppressive drugs for kidney transplantation: A systematic review and meta-analysis. Am J Nephrol 2016;44:206-18. https://doi.org/ 10.1159/000449020

3. Liu JY, You RX, Guo M, et al. Tacrolimus versus cyclosporine as primary immunosuppressant after renal transplantation: A meta-analysis and economics evaluation. Am J Ther 2016;23:e810-24

https://doi.org/10.1097/MJT.0000000000000150

4. Nassar Mogahid Yahi'a, Al-Shamahy Hassan Abdulwahab, Al-Samawi Abdullah Saleh; Abu Asba, Nagieb Waza'a, ElNono Ibrahiem Husain, Masood Haitham Abdulwahab. Human Leukocyte Antigen Class I and II Variants in Yemeni Patients with Chronic Renal Failure. Iran J Immunol 2017; 14(3):1-6. PMID: 28919587

5. Nassar MY, Al-Shamahy HA, Haitham A. A. Masood. . The Association between Human Leukocyte Antigens and Hypertensive End-Stage Renal Failure among Yemeni patients Sultan Qaboos University Med J 2015;15 (2):e241249. PMID: 26052458

6. Sahman M, Al-Mousawi M, Hayati H et al. Result in 158 consecutive cadaveric renal transplantation. Transplant proc 2005; 37:2965-2966.

https://doi.org/ 10.1016/j.transproceed.2005.08.019
7. El-Nono IH, Al-Ba'adani TH, Abu Asba NW et al. Adult -toadult living related donor, renal transplantation in Yemen : The first experience. Saudi J kidney Dis Transplant 2007;18(2) : 265-269.

8. Liu H, Chou M, Kao M. Allograft dysfunction in association with cytomegalovirus in renal transplant recipient. Division of Nephrology, Department of Internal Medicine, China Medical College Hospital, Taichung, Taiwan, R.O.C. 2003; 17 (2): 95-98. https://doi.org/10.21037/tau.2018.10.14

9. Weikert CB, Blumberg AE. Viral Infection after Renal Transplantation: Surveillance and Management. Clin J American Soc Nephrol 2008; 3: S76-S86. https://doi.org/10.2215/CJN.02900707

10. Vicenza CR, Vicenza SC, Bergamo GR. Kidney Transplantation: Strategies to Prevent Organ Rejection; 2005; VII. https://doi.org/10.1159/000082068H

11. Penninga L, Møller CH, Gustafsson F, Steinbrüchel DA, Gluud C. Tacrolimus versus cyclosporine as primary immunosuppression after heart transplantation: Systematic review with meta-analyses and trial sequential analyses of randomised trials. Eur J Clin Pharmacol 2010; 66:1177-87. https://doi.org/10.1007/s00228-010-0902-6.

12. Mathew TH, Rao M, Job V et al. Post-transplant hyperglycemia: a study of risk factors. Nephrol Dial Transplant 2003; 18: 164-71. https://doi.org/10.1093/ndt/18.1.164

13. Drachenberg CB, Klassen DK, Weir MR, Wiland A, Fink JC et al. Islet Cell Damage Associated With Tacrolimus And Cyclosporine: In Morphological Features In Pancreas Allograft Biopsies And Clincal Correlation. Transplantation: 1999; 68: 396-402. https://doi.org/10.1097/00007890-199908150-00012.

14. Boots JMM, Van Duijnhoven EM, Christiaans MHL et al. Glucose metabolism in renal transplant recipients on tacrolimus: the effect of steroid withdrawal and tacrolimus trough level reduction. J Am Soc Nephrol 2002, 13:221. PMID: 11752041

15. Mayer A. Chronic rejection and graft half-life: five-year follow- up of the European tacrolimus multicenter renal study. Transplant Proc 2002; 34:1491. https://doi.org/ 10.1016/s0041-1345(02)02942-1

16. Fort E, Mercadal G, Berlana D, Martorell C, Badia MB, GilVernet S, Jòdar R. Diabetes mellitus associated with tacrolimus in renal transplant.The European $\mathrm{J}$ Hospital Pharm Sci 2005; 11: $74-77$. https://doi.org/10.1016/j.transproceed.2007.06.035

17. Silva FR, Silva LB, Cury PM, Burdmann EA, Bueno V. FTY720 in combination with cyclosporine is analysis of skin allograft survival and renal function. Int Immunopharmacol 2006; 6:1911-1918.

https://doi.org/10.1016/j.intimp.2006.07.014

18. Amend WJ, Vincenti F, Tomalnovich SJ. The first three posttranspalnt month's. Handbook of KT 2005; 8:213-228. https://doi.org/10.1155/2020/1938703

19. Danovitch GM. Hand book of kidney transplantation 4th edition. 2004; 72-134.

20. Campanholle G, Galvao M, Cenedeze MA, Depaul V, Teixeira A, dosreis MA. Dual response of animals with chronic cyclosporine nephrotoxicity to an acute hemic injury. Transplantation proceedings 2006; 38, 3341-3343. https://doi.org/10.1016/j.transproceed.2006.10.096

21. Kopp JB, Kloman PE. Cellular and molecular mechanisms of cyclosporine nephrotoxicity. J Am Soc Nephrol 1990; I: 162-179. PMID: 2104260

22. Stegall MD, Simon M, Wachs ME, et al. Mycophenolate Mofetil decrease rejection in simultaneous pancreas-kidney transplantation when combined with tacrolimus or cyclosporine. Transplantation 1997; 64:1695. https://doi.org/10.1097/00007890-199712270-00011

23. Morris-Stiff G, Khan A, Quiroga I, Baboo R, Jurewicz WA. Immunosuppression in renal transplantation BMJ 1999; 319:1136. https://doi.org/10.1136/bmj.319.7217.1136

24. Burke JF, Pirsch JD, Ramos EL, Salmon DR, Stablem DM, Van Duran DH, West JC. Long -term efficacy and safety of 
cyclosporine in renal transplant recipients .The New England J Med 2007; 331:358-363. https://doi.org/10.1056/NEJM199408113310604

25. Armin W, Ursula S, Alfred F, Lothar A, et al. Hepatocellular Effects of Cyclosporine A and it's Derivative SDZ IMM 125 in Vitro. The J Pharmacol Exp Therap 1998; 284:817-825. PMID: 9495838

26. Martendels 32. The complete drug reference 1999; 519-525 https://doi.org/10.3163/1536-5050.100.1.018

27. Fabrizi F, Bunapradist S, Martin P. Kidney transplantation and liver disease. Handbook of kidney transplantation 2005; 11: 335-343

28. Guichard SW. Nutrition in the kidney transplant recipient. Handbook of KT 2005; 18:477-478 https://doi.org/10.3389/fmed.2018.00302

29. Muller T, Koeppe S, Al-beitrer K, et al. Ped Nephrol 2003; 18: 939-942.

30. Akman UM, Afsar B, Sezer S, Ozdemir FN, Haberal M. Lipid profile during Azathioprine or Mycophenolate Mofetil combinations with cyclosporine and steroids. Transplantation proceeding 2007; 39: 135-140. https://doi.org/10.1016/j.transproceed.2006.10.210

31. Danovitch GM. Immunosuppressive medications and protocols for kidney transplantation. Hand book of kidney transplantation, $4^{\text {th }}$ edition 2005; 4: 72-91.

https://doi.org/10.1046/j.1523-1755.2001.00501.x

32. Benjamin E, Coico R, Sunshine G. Immunology-A short course. 4th edition.2000; 389-390.

33. Winkler M, Schulze F, Jost U, Ringe B, Pichlmayr $R$. Anemia associated with FK 506 imunosuppression. Lancet 1993:341:1035-1036. PMID: 7682273

34. De-La-Sera HC, et al. Tacrolimus-induced bone marrow suppression. Lancet 1997; 350:741-15.

35. Sollinger HW. US renal transplantation Mycophenolate Mofetil study group for the prevention of acute rejection in primary cadaveric renal allograft recipients. Transplantation $1995 ; 60: 225-232$ https://doi.org/10.1097/00007890-199508000-00003

36. Dejong DJ, Sayler DJ. Possible cyclosporine-associated thrombocytopenia. DICP Ann Pharmacother 1990; 24:1007. https://doi.org/10.1016/j.hoc.2007.06.005

37. Brunet L, Miranda-Rius, Farre M, et al. Gingival enlargement induced by drugs. Drug Saf 1996; 15:219-31. https://doi.org/10.2165/00002018-199615030-00007

38. Stefanidou V, Liakopoulos V, Eleftheriadis T, Anifandis G, Mertens PR, et al. Expression of transforming growth factorreceptor II $m$ RNA in cyclosporine-induce gingival overgrowth. Transplantation Proceedings 2006; 38:29052908. https://doi.org/10.1016/j.transproceed.2006.08.151

39. Chand DH, Quattrocchi J, Poe SA, et al. Trial of metronidazole vs. azithromycin for treatment of cyclosporine-induced gingival overgrowth. Pediatr Transplant 2004; 8: 60-64. https://doi.org/10.1046/j.1397-3142.2003.00067.x

40. Montagnino G, Kramer BK. Efficacy and safety of tacrolimus compared with cyclosporin microemulsion in kidney transplantation: twelve-month follow-up. Transplant Proc 2002; 34: 1635-1637. https://doi.org/10.1093/ndt/gfh739

41. Raimund M. Efficacy and safety of tacrolimus compared with cyclosporin microemulsion in renal transplantation: a randomized multicentre study. Lancet 2002; 359: 741-746. https://doi.org/10.1016/S0140-6736(02)07875-3

42. Gafter-Gvili A, Sredni B, Gal R, et al. Cyclosporin Ainduced hair growth in mice is associated with inhibition of calcineurin- dependent activation of NFAT in follicular keratinocytes. Am J Physiol Cell Physiol 2003; 284: C1593603. https://doi.org/10.1152/ajpcell.00537.2002

43. Kubak BM, Maree C, Pegues DA, Hwany A. Infection in kidney transplantation. Handbook in kidney transplantation $2005 ; 10: 280-329$

https://doi.org/10.1007/978-3-319-19617-6_22

44. Prisch JD,Sollinger HW, Smith C. Kidney and Pancreas transplantation in diabetic patients. Handbook in kidney transplantation 2005; 14:391- 398. https://doi.org/10.5500/wjt.v9.i4.81

45. Bartholomeusz B, Hardy KJ, Nelso AS, Philips PA. Modulation of nitric oxide improves cyclosporine A-induced hypertension in rats and primates. J Hum Hypertens 1998; 12: 839-844. https://doi.org/10.1038/sj.jhh.1000709

46. Morales JM, Andres A, Rengel M, Rodicio JL. Influence of cyclosporin, tacrolimus and rapamycin on renal function and arterial hypertension after renal transplantation. Nephrol Dial Transplant 2001; 16: 121-4. https://doi.org/10.1093/ndt/16.suppl_1.121

47. Koomans HA, Ligtenberg G. Mechanisms and consequences of arterial hypertension after renal transplantation. ransplantation 2001; 72: 9-12. https://doi.org/10.1097/00007890-200109271-00004

48. Curtis JJ. Posttransplant hypertension. Transplant Proc 1998; 30: 2009-2011. PMID: 17955265

49. Margreiter R. European Tacrolimus vs Ciclosporin microemulsion renal transplantation study group. Efficacy and safety of tacrolimus compared with ciclosporin microemulsion in renal transplantation: a randomised multicentre study. Lancet 2002; 359: 741-746. https://doi.org/10.1111/tri.12716

50. Henry ML. Cyclosporine and tacrolimus (FK 506). A comparison of efficacy and safety profiles. Clin Transplant 1999; 13: 209-20. https://doi.org/10.1034/j.1399-0012.1999.130301.x

51. Siddqi N, Hairharan S, Danovitch G. Evaluation and preparation of renal transplant candidates. Hand book of kidney transplantation 2005; 6:170-183. 